\title{
5. Through a Glass Darkly: The vicissitudes of budgetary reform in Australia
}

\author{
John Wanna
}

\section{Introduction}

The budgeting of public resources is supposedly one of the most crucial tools in public governance. Budgets and the associated allocation and management of financial resources are a fundamental source of power to governments and money invariably lies at the heart of almost all public policy decisions and activities, as Peter Walsh (1995) once argued. It provides governments with their wherewithal, their real authority and the ability to achieve their aims. Ostensibly, budgets allow governments to plan and fund their priorities, to resource existing commitments, to reduce allocations to less preferred activities, or change the tax-benefit trade-off between citizens and government (Wildavsky and Caiden 2004). This is the theory, but practice is very different and much more complicated.

Budgets are multiple things to multiple constituencies; they serve many purposes and functions across government and between government and the community. Their functions include economic management and macroeconomic policy, sustaining public finances, fiscal policy, revenue functions, investment intentions, expenses, allocative functions, technical efficiency, performance evaluation and accountability review (see Wanna et al. 2003, pp. xxix-xxx). These functions are not necessarily complementary, consistent or cumulative. Hence, unlike private choice, public budgeting is a complex, repetitive set of collective choices about resources and provisions various governments consider society needs (some of which relate to given 'mandates' but other choices no one can remember making), and then accounting for these choices and decisions.

Budgets have long been a traditional ritual of modern government. They are a major undertaking of government, performed annually. They are political exercises as much as administrative exercises. Our governments invest a great deal of time, resources and political capital in putting the annual budget together and selling it. They take great pride in their successful delivery and reception in Parliament, and with the media, interest groups and wider community. They 
are frustrated and perplexed when budgets flop or receive a less than rapturous ovation from stakeholders and critics. Budgets are also a routine confidence issue and governments can themselves fall if their budgets are rejected or deferred.

But, for the purposes of this chapter, it should be recognised that budgets are also hard to put together and there may be little scope for flexibility in the overall budget. They are massive in scope; there are many competing demands; there are many stakeholders and recipients involved; they often defy orderliness or tidiness; they defy planning logics and mathematical rationalities. They are notoriously difficult to compile and keep together. There are masses of information to be assembled, weighed, evaluated and used as foundations for other calculations and projections. They are constantly buffeted by events, changing perceptions and shifting interpretations. They simultaneously look backwards and forwards - governing from behind to meet the challenges of the future.

Budgets and budget formation are also highly secretive and undertaken away from the glare of publicity (see Heclo and Wildavsky 1974; Wanna et al. 2003, p. xxxiii). They involve back room processes and decisions, internal rules and conventions, ways of doing things that are not disclosed. Rules are changed periodically often to disadvantage certain claimant groups or agencies. Ministers may 'see' only a thin veneer of the budget - generally those elements that concern them or for which they have personally lobbied. We, the public, generally see but the tip of the iceberg and have to guess what goes on under the surface. Furthermore, budgets are supposedly an accountability device, transparent and open to scrutiny and requiring legislative authorisation (as a form of control on executive government). Yet, budgets are presented in ways that differ markedly from the ways they were put together. It is as if we have two separate processes or logics of action that hardly interrelate with each other. As will be argued, despite claims of greater openness, this lack of clarity and transparency remains a major problem. The political executive likes to keep the legislature guessing, at arm's length and one or two steps behind the action. There are problems with the alignment of data and activities, figures and results; it is hard to identify or distinguish 'old money' from 'new money', offsets from new programs, and how changed preferences for reporting activities vary from previous years.

Once budgets are consolidated and formally presented they are judged by the community, the media, money markets, commentators, lobbyists, and the government's political opponents. There is a tendency here to see success in the form of projected surpluses - the notion that government can pay for itself rather than that government is using its funds wisely. So surpluses (especially year-onyear), as Australian treasurers are fond of saying, indicate we are managing well and practicing sound financial management. Like George Orwell's farm animals, governments seem to bleat 'one surplus good, two surpluses better'. 
But are we managing well? Does the existence of a surplus necessarily mean that we are following best practice budgetary and financial management? The Howard government's finance minister, Senator Nick Minchin, in his opening address to the senior budget officials (OECD) meeting in Sydney June 2006 (Minchin 2006), implied that this was the only measure for judging budgetary performance as he unfavourably compared state budget deficits with federal surpluses. This may not be the most appropriate indicator of success (nor a fair comparison). Moreover, the budgetary system under the Howard government did not really experience adverse economic circumstances and so was not tested. After 1997, the Howard government enjoyed high economic growth and a mining boom; it did not face significant fiscal pressures and presided over massive year after year spending increases only surpassed by even more massive revenue receipts (see Wanna et al. 2000, p. 258-269; Laurie and McDonald 2008). Arguably, the reluctance to seriously reform the tax side of the budget equation means that taxation revenues give the appearance of good budgetary practice, without it necessarily being so.

In this chapter, I explore briefly the imperatives for budgetary reform and comment on where they came from. I then trace and explain the particular trajectory followed in Australia and note the vicissitudes of budget reform over time. I do not attempt a comprehensive detailed overview of budget reform, as I have undertaken that in other publications (Wanna et al. 2000; O'Faircheallaigh et al. 1999; and Wanna et al. 2003, and later in Wanna et al. 2010). Rather, I will pick out some of the key successes that have improved our management of public finance, after which I indicate a few weaknesses and deficiencies in our current system — highlighting the problems associated with the present outcomes framework. I explore some dead ends and dry gullies we once went up before deserting them. Then I raise some problems with our present practices of budgetary reporting and accountability. Finally, I offer a series of propositions from my research to perhaps challenge preconceptions about the overall nature of budgetary reform.

\section{Background: Traditional budgets and the imperatives for budgetary reform}

Conventional wisdom, and much of the relevant academic literature over the twentieth century asserted that traditional budgets and internal budgetary processes were conservative, incremental and risk-averse (Wildavsky 1964). They locked in governments and gave them limited scope for reallocation. They were often beyond political control or influence and, over the post-war era, expenditures grew less according to political preferences than to internal logics 
of growth and augmentation. International comparative analyses of expenditure increases over this period highlight the consistency of growth patterns within distinct national clusters (Scandinavian, Anglo-American and Continental European: see Castles 1999). Ministers often played a relatively insignificant role in the process except for the presentational functions and events (for example, introducing the budget to the legislature, or selling it afterwards). Many cabinets were not involved in setting aggregate budgetary frameworks or informed about decisions in detail. Because most of the new policy decisions and commitments feeding into a collective budget were made on the basis of comparing the relative merits of rival bids, budgetary processes had to find ways to reduce or mitigate political conflict through the proliferation of rules, disciplines and timelines (see Wildavsky 1964). Budgeting became acknowledged as an annual repetitive cycle where adjustments were made at the margin.

So, as a means of rationing claims from 'spender' departments, budgeting was undertaken largely in secret using bilateral negotiations or side deals. A semblance of control over the process - often interpreted as exercising power over the public purse - gave budget guardians such as treasuries or finance departments the illusion of power. They performed the role of devil's advocates, but were often outplayed or outmanoeuvred by spending agencies who regularly overspent their allocations. The command-post mentality of central budget agencies fitted only with a budgetary system based on input allocations within a punitive administrative culture, which was increasingly seen as dysfunctional to modern governance (Schick 2001; Wanna et al. 2003). Moreover, the role performed by central guardians was reactive rather than strategic, and generally prevented or restrained governments from doing the things their component parts had proposed.

Such input-driven systems remained largely unchallenged until the economic and fiscal crises of the 1970s and 1980s, when governments presided over large and repeated deficits, and debt levels rose because of structural budgetary imbalances. Compounding resource problems saw governments gradually take a closer interest in both their fiscal policy settings and internal budgetary processes (Keating 1990; Keating and Holmes 1990; Keating and Dixon 1989). New governments proposed various half-baked or speculative suggestions for budgetary reform, often not worked out in detail (see ALP 1983; Australian Government 1984), or issued persuasive arguments on the need for substantial reform (for example, New Zealand Treasury 1984). If politicians were to be held accountable for the consequences of poor budgeting outcomes, then they and their senior advisers felt they ought to exert greater influence over crucial aspects of government budgeting, including aggregate-setting and discretion over the allocation of the 'base' and new money/new policy proposals. 
Governments began a process of containing expenditure growth, targeting spending, using co-payment and user-charging devices to ration and direct resource public provision. The early methods were fairly crude, blunt and limited in their effectiveness. The Fraser governments (1975-83) attempted budget control through arbitrary top-down ceiling controls, clawbacks and across-the-board cuts. The subsequent Hawke (1983-91) and Keating (199196) governments forced managers to manage within prescribed resource limits set over the medium term, thereby bringing aggregate budgets under control (see Wanna et al. 2000). By the mid-to-late-1980s governments had made the difficult transition from consecutive high deficits in final budget outcomes to annual surpluses often exceeding budgetary forecasts. Budgets and financial management in the modern expansive state had been brought under administrative control possibly for the first time since the parsimonious nineteenth-century era of small government liberalism.

This is probably the most significant single achievement of modern budgetary reform and the associated adoption of sophisticated information technology systems. Governments, if they so desired, now had the capabilities to be able to bring their budgets under control and into balance. But as the years 1990-92 showed, and then again in the global financial crisis after 2008, public budgets were not recession proof; a point that is still evident in many OECD nations such as the US, the UK, Ireland and most of southern Europe.

There were many budgetary and financial management adaptations that were regarded as successful and which have proved useful in improving resource utilisation. We should acknowledge these and give credit - as I will later turn to highlight some deficiencies in the present systems. Successful innovations have included:

- A consolidated budgetary process allowing the comparative merits of budgetary proposals to be judged and argued out with a consolidated reporting of budget measures;

- A strong Expenditure Review Committee (ERC) of Cabinet with senior guardian ministers able to impose discipline over the budget process;

- The 'medium-term economic framework' (MTEF) that sits on the formally documented 'fiscal strategy statement';

- One-line operating budgets providing greater flexibility with departmental expenditures and expenses;

- Full cost budgeting on an independent accrual accounting basis, providing systematic recognition for assets and liabilities as well as revenue and expenses;

- A tighter focus on core public sector activities (moving out of Government Business Enterprises, and other entities) through privatisation of functions 
not fitting the current role of government and restructured corporate governance arrangements to improve accountability for the remaining government functions;

- Greater attention to a results-based orientation in public finance in the formulation process, in-year operations and with budget reporting;

- Offsets and matching saving requirements from bidding departments have provided, on occasion, a test of priority and seriousness of budget submissions;

- Asset recognition, asset management and property leasing across government.

Australia and New Zealand were soon regarded as leaders in the field. Many of the budgetary and IT reforms practiced here were taken up internationally as other countries adopted improved practices in their own jurisdictions. Considerable policy transfer occurred especially across the OECD (see Wanna et al. 2010); some simply through information exchange about local innovations; some through the direct importation, copying and adaptation of innovations developed elsewhere; some through the dissemination of endorsed practices (best practice principles) by the OECD and IMF (for example, OECD 2001; and by the Senior Budgetary Officials meetings, OECD 2004; IMF 1999); and some through the bullying of donor financial institutions anxious to proliferate their notions of good governance structures to local polities before releasing funds. In addition, legions of consultants, former budgetary officials and occasional academics cruised the world proselytising the merits of various reform initiatives (usually ones with which they had been personally associated, but thereafter presented as frozen snapshots in time rather than intermediate stages in a longer evolution of change).

The transfer of budgetary rules and procedures has included legislative instruments (for example, the Fiscal Responsibility Act 1994 of New Zealand was later replicated in Australia in the Charter of Budget Honesty Act 1998, and adapted almost simultaneously by various state governments too: see Wanna 2006). It has included the uptake of substantive innovations (for example, oneline budgets, MTEF, centrally imposed aggregate spending limits, Cabinet budget review committees, and the consolidated running costs arrangements, many of which were exported from Australia and New Zealand to countries such as the Netherlands, Canada, Denmark and Ireland, as well as many smaller Asian and Pacific nations). In addition, improved accounting techniques have received international acceptance (such as internationally recognised standards, accrual budgeting systems). Not all countries achieved similar rates of progress. There was much cultural and institutional adaptation, and there still remains much diversity in country-specific arrangements. However, a significant group of OECD nations now operate much more sophisticated budgetary systems with far greater control over the total budget. 


\title{
Explaining Australia's ad hoc trajectory of budgetary reform
}

\begin{abstract}
Australia's trajectory or path dependency in budget reform was far from linear and planned. It was not programmatic or designed according to an overall template or blueprint. There was no rational design, no calculated schedule or intended agenda of reform. Nevertheless, governments and their central budget agencies have generally insisted budget reform was rational, planned, linear, always anticipated, and a process of progressive consolidation - when often it was nothing of the sort. The Department of Finance was once renowned for saying there were never 'problems' overseeing the budget process, just 'challenges'.
\end{abstract}

The process of reform was piecemeal and staccato, where the consequences or change are often unintended and unforeseen. As such, various reforming governments from Fraser to Hawke and Keating to Howard embarked upon a meandering journey of budget reform. The journey was associated with changing circumstances and technical possibilities as well as by changing considerations - getting control of expenditures, consolidating operating budgets, identifying programs and sponsoring program management, separating 'program' costs from running costs, using various costing methodologies, and the use of market delivery mechanisms.

The process was ad hoc, but not totally random. Instead, some broad principles and directions can be traced that shaped the government's thinking. These broad principles followed rather than led the unfolding path of experimentation. Over time, governments endorsed the principles of devolution and devolved responsibilities, of a results-based focus in spending allocations. There were disputes and disagreements along the way between advocates of rival directions - especially between 'central controllers' and 'devolved managers'. In the process many players and agencies suffered identity crises - what were they doing, why, how, what value did they add to the process (this included agencies such as the Treasury, Finance, the Auditor-General, and even Parliament). As victors and survivors get to write history, the eventual winners were able to rationalise the sustainable components of the process much later (see Management Advisory Board 1997; Department of Finance and Administration 1998). They then insisted that the successful reforms had been intended from the outset, that they knew they would work, were augmented and extended when successful, and then documented and if necessary legitimised through changed legislation or budget rules. Myth was built on myth, and was disseminated internationally through the OECD and senior budget officials meetings (see Chan et al. 2002). 
Elsewhere I have clustered the surviving reforms under six headings to indicate the different trajectories and objectives of many of the reform experiments (O'Faircheallaigh et al. 1999). These headings are:

- Political and ministerial reforms - for example, ERC, approving fiscal targets, political discipline, spending rounds consolidated to specific windows;

- Budgetary and technical reforms - for example, consolidation of running costs, one-line budgets, outcome budgeting, various incentive arrangements with agencies;

- Managerial and systems reforms - for example, program management, business plans, management information systems;

- Program evaluation reforms - for example, evaluation processes, compulsory evaluations, performance audits, benchmarking, triple bottom line reporting;

- Market-based and contract management — for example, competitive tendering, outsourcing; and

- Accounting and reporting reforms - for example, accrual budgeting, improved integrated reporting, financials and non-financials.

In the struggle for the hearts and minds of the reform movement, the so-called 'managerialists' won the day (those seeking not to reduce the state but to make it perform better and deliver more efficient and effective services). So, Australia took on a pragmatic, managerialist-inspired approach to budgetary reform, accompanying an expansionist Commonwealth government with galloping expenditures and expanding policy horizons (Laurie and McDonald 2008). The new legions of public managers became the specific focus and essence of the changes. Australia's budget reform trajectory consciously and unconsciously privileged the managers. Managerial incentives became central to the character of reform and its momentum. It also became highly path-dependent. In many ways Australia's ad hoc trajectory was a 'provider-led' reform strategy driven by champions in central agencies (with a few supporters out in line agencies) who argued the case that program managers should be given more operational discretion. Put differently, the program managers captured the reform process, implying that the 'providers' rather than the 'principals' ran the show - distinctly unlike the New Zealand trajectory. Australia is an example of bureaucratic capture of budget reform.

The path of reform was clearly not neo-liberal in character (and it is a misdiagnosis to see it in such terms as some have) but dedicatedly managerialist - oriented around 'doing more', 'making managers manage', improving 'value for money' (Keating 1989). It gave executives resource latitude within a managerialistdriven system. The presumption was that the spenders and program managers would manage their budgets better and more conservatively if allowed to do so 
- and using the potentialities of devolved financial management most program managers were able to come in under budget so that agencies were able to carry forward funds year after year. Under new public management and then accrual budgeting in an 'outcomes framework', spenders needed to exercise their own guardian roles and 'behave' within the negotiated resource limits (see Kelly and Wanna 2001). While constraints were important, managers were given flexibility to manage within program structures, and told to identify outputs and results.

By omission or contrast, Australia's reform path gave less emphasis to other factors such as accountability, performance, 'policy integrity' or policy effectiveness. We can contrast the Australian trajectory with those found in other nations that have undertaken budgetary reform. Canada placed more focus on policy integrity, policy priorities and policy rationing. New Zealand centred its approach on ministers purchasing outputs from managers. The UK placed emphasis on systematic administrative reviews of spending and later on combined outputs (joined up initiatives). The Netherlands emphasised the central withdrawal from social services and the devolution of service delivery to regional and municipal governments.

In Australia, management instruments and budgetary instruments were blended and overlaid upon each other. Resource allocation shifted from a historical fascination with 'front-end' analysis (preoccupied solely with input data and detailed spending amounts on itemised units), to an MTEF oriented towards results (outcomes and/or outputs) with considerable devolution of resource usage to operational management, and eventually the full costs of services acknowledged in budget allocations (a performance and activity focus).

Importantly, Australia's promotion of budgetary reform was often the initial catalyst and main driver of wider public sector reform and improvements in public management. Indeed, some would argue that budgetary reform has significantly biased the nature of new public management especially in the Anglo-American nations, giving a strong resource-orientation to the reforms (Wanna et al. 2000, Chapter 12; Halligan 2004). Thus, management reforms, business plans, citizens charters, outsourcing, the streamlining of industrial relations, and human resource management reforms were often premised or built on the foundations of budgetary reform. Some would further argue that budgetary orientations and practices drove policy choices especially in the 1980s and mid-1990s - when portfolios and agencies were allowed to reallocate internally and clawbacks such as the efficiency dividend encouraged agencies to invent new policy bids to replenish their operating budgets.

To some extent Australia's managerialist trajectory hit a brick wall when a budgetary 'outcomes/outputs framework' was superimposed over the system. This was introduced in 1999-2000 as a blanket-like framework that supposed it 
could be applied equally to all parts of the public sector. Initially, the outcomes framework was welcomed and received a positive reception (by Cabinet, many individual agencies, by parliamentary committees and the AuditorGeneral). There was much hype about the integrated and interlocking nature of the 'backward mapping' decision process - going from desired outcomes to deliverable outputs to budget allocations - or at least in theory (see Chan et al. 2002). But many of these promises led to disappointment (see Tanner 2006 for the ALP's 'Operation Sunlight' proposals).

\section{Problems with the outcomes framework and budget processes}

To date, it is clear there are a number of fundamental problems that have arisen with our reforms.

First, the reforms have been aimed at better internal resource utilisation by operational managers rather than at strategic allocations or allocative efficiency at the whole of government level. We can ask a series of questions here: to what extent does the budget process allow governments to undertake strategic thinking and implement chosen strategies, especially the possibilities for strategic decision-making/action by governments over policy issues of concern to them? Are budget processes aligned with the government's strategic directions and leadership style?

There is an empirical question as to how far strategic considerations can be addressed through the budget process, and this varies from jurisdiction to jurisdiction. Across the OECD (especially in the parliamentary democracies) we can detect various ways in which political actors (ministers and especially prime ministers) have sought to enhance their involvement in budget decisionmaking, usually to increase their influence beyond merely ratifying decisions taken elsewhere. Cabinets and senior financial ministers are more involved in determining the initial framing decisions concerning budget aggregates and underlying assumptions (for example, the prudential budgeting used by Canada, Sweden's expenditure envelopes, or Australia's medium-term strategy with budget aggregates and forward estimates). Some nations have enhanced the power of ministers to determine new policy initiatives on specific spending cabinet committees (for example, Canada's twin cabinet policy committees for economics and social policy). Governments have also driven major cutting exercises or deep review into base spending areas or targeted areas for cutbacks 
(Australia in the mid-1980s, then in 1996-97 and then after the election of the Rudd government in 2007-08; Canada in 1995-96 with the 'program review' exercise). ${ }^{1}$

Although results-related in format, the Australian 'outcomes framework' has significant problems that have hardly been addressed since its introduction in 1999. The main exception was the opposition Labor Party's 'Operation Sunlight' document (Tanner 2006), which provided a critical review. But most of its recommendations were not implemented. Cynics would argue that allocation to 'outcomes' is a disguise and that in reality it is a glorified framework for base budgeting at the agency level. Budgetary systems that protect the base budget of agencies ('base-plus' budgeting) are relatively impervious to major changes in strategic direction from the centre. Moreover, the emphasis on outcomes has arguably distracted attention away from analysing the ongoing activities of government. It may be possible for some decentralised strategic realignment to be exercised within agencies or departments providing they have the discretion, scope and capacity to move resources without unduly restrictive rules operating from the centre or having to curtail/downsize essential services. Without large surpluses, base budgeting (including standing appropriations and non-discretionary spending) is likely to account for up to 95 per cent of available resources in the budget round, especially if jurisdictions have large intergovernmental responsibilities and recurrent spending commitments (for example, sub-national jurisdictions).

Related to the budgetary process, and feeding in at critical moments, is the increasing use of politically articulated 'top-down' strategic priorities, which are essentially forms of policy rationing. In Australia, a small group of very senior ministers participate in an annual two-day retreat (the 'senior ministers' review') in late November to determine key government priorities (usually three to four key priorities) for the upcoming budgetary formulation round (commencing December to March). The Prime Minister then writes out to all Cabinet and other ministers informing them of the priorities to be used in framing the forthcoming budget. Other policy issues not on the senior ministers' list have less chance of winning ERC approval in the process.

Prime ministers have further enhanced their discretion over the budget process by imposing greater personal determination over spending initiatives (which can be used either for strategic or expedient purposes). Prime ministerial preferences, formulated perhaps with input from advisers in their private office or department, can predetermine agendas or set key priorities without input from Cabinet colleagues, or be decisive in determining final spending items (and

1 See Appendix 1 at the end of this chapter discussing what a more strategic budget process would look like and what kind of decisions it might contain. 
the timing of them). The Commonwealth's \$10 billion Murray-Darling Basin water initiative, announced in January 2007, was a case in point (see the critique by the then Treasury Secretary, Ken Henry 2007). The personal preferences of Prime Minister John Howard were increasingly imposed throughout his long tenure prior to and through the senior ministers' review. This process is backed by charter letters and annual performance letters from the Prime Minister to ministers and departmental heads that provide explicit details on government expectations of the portfolio, policy priorities and strategic issues.

But these windows for strategic interventions by senior politicians do not achieve much if the politicians themselves do not choose to be strategic or avail themselves of the opportunity. The Australian Cabinet has progressively downsized the amount of business going to Cabinet (reducing the detailed workload), ostensibly to allow Cabinet to focus on the important issues to the government as a whole. Some Cabinet meetings have been given over to 'strategic Cabinet days' at which a senior minister will brief Cabinet on a selected policy topic (usually without accompanying briefing documents or associated paperwork, and with PowerPoint presentations the preferred mode of address) and no routine matters are presented. In standard Cabinet meetings a proportion of time can also be set aside for strategic discussions. These developments are meant to provide Cabinet with ample opportunities to debate issues without officials and without mountains of paperwork to digest.

However, while some of these events have been regarded as valuable sessions, others have degenerated into pep-talks, rallying speeches, discussions of political tactics or to mulling over the most recent opinion poll results. Hence, simply allowing ministers more time to consider strategic issues as part of the processes of collective responsibility does not mean that they will think or behave strategically. There are many criticisms of government remaining reactive and preferring expedient or short-term adjustments in policy settings.

A former head of the South Australian Cabinet office, Adam Graycar, recently argued that strategic initiatives were often not addressed through the budget process but instead dealt with on the side by 'passing the hat around'. He found that

colleagues in line agencies are so very tightly constrained financially that they cannot see beyond their core business and agency boundaries. They have very little financial flexibility, and Treasury bureaucrats in our jurisdiction, like their counterparts in other jurisdictions, have acculturated into knowing the price of everything and the value of nothing ... The budget process is a mightily inefficient process of being barely accountable for funds previously allocated, or fighting ferociously for crumbs with which to fund new programs or respond to 
cost pressures. If a new proposal involves contributions from, or benefits to multiple agencies, then we have a process not unlike passing the hat around for funds (Graycar 2007, p. 13; see also Graycar and McCann 2012).

Second, outcomes and objectives are only loosely related to the resource appropriation process or performance reporting process. Outcomes are expressed at a high level of abstraction, often as vague composite expressions. Some are inspirational 'feel-good' phrases under which almost anything can fall or be counted. Some provide a grand edifice under which relatively mundane activities are found (for example, the Department of Finance's 'Efficient Functioning of Parliament' which provides drivers for the car fleet and the checking of parliamentary receipts and entitlements). This problem has been identified by the Australian National Audit Office (ANAO) and some parliamentary committees on a number of occasions but little has been done to rectify the concerns (see Senate Standing Committee on Finance and Public Administration 2007). The ANAO has warned agencies to express their outcomes with 'sufficient specificity' to ensure that they are meaningful. Yet departments continue to produce many woolly or platitudinous statements of intent in their portfolio budget statements:

- Efficient Functioning Parliament(Department of Finance and Administration);

- Strong and Resilient Communities (Department of Families, Community Services and Indigenous Affairs);

- Families and Children have Choices and Opportunities (Department of Families, Community Services and Indigenous Affairs);

- Higher Productivity, Higher Pay Workplaces — previously Higher Productivity, Higher Wages (Department of Employment and Workplace Relations);

- Assisting Regions to Manage their own Futures (Department of Transport and Regional Services); and

- Public Understanding in Australia and Overseas of Australia's Foreign and Trade Policy and a Positive Image of Australia (Department of Foreign Affairs and Trade).

Many of these are clearly omnibus outcomes in that contributions to the outcome could come from many sources, agencies, policies, events and circumstances. Many agencies across government may make contributions to such intentions (for example, climate change, productivity, or a sustainable economy). It is a myth that all outcomes are conveniently located in one agency (or even one division of one agency) even if other agencies may assist in the delivery of particular outputs (for example, Centrelink assisting with the Department of Families, Community Services and Indigenous Affairs' family payments). Across 
the Commonwealth, one division of a department will nominally have sole responsibility for one outcome - which could be highly systemic or generic in character, when in reality the agency only makes a small contribution to the desired outcome. This insistence on outcomes each located within one agency is a budget rule of convenience for the central agencies not a reflection of the world of public policy.

There have been criticisms of the degree to which outcomes are changed or subjected to revision — with approximately 20 per cent of agency outcomes experiencing some changes over the past few years. But as the ANAO (2006) has pointed out, while some change may be justified, changes to outcome statements erode the capacity of external scrutineers to follow budget activity and performance over time. At present, agencies are required to provide explanations of the changed formulation from year to year and translation maps to allow comparative scrutiny in portfolio budget statements, but the changes are rarely (if ever) challenged or even discussed by Parliament. The only significant challenge to outcome descriptions in recent years, though ultimately impotent, has come through the Combet $v$ Commonwealth High Court challenge, which examined the validity of certain advertising expenditure under the 'higher pay, higher productivity' outcome for the Department of Employment and Workplace Relations. By a margin of five to two, the court found that outcomes were a legal form of appropriation under which diverse items of spending could be made; in essence, the court backed executive privilege in this instance (and argued it was not the role of the courts to decide what was government policy and it was better for parliament to decide such matters). But it could take a different view in the future and force subsequent governments to specify their spending more precisely (as the two dissenting judges implied).

In performance management and reporting, secretaries, executives and program managers have direct incentives to deliver on budget or within budget even under-budget, but certainly not over-budget — rather than seeking to maximise outcomes. At the state level, the enormous problems with child safety that were historically swept under the carpet indicates a history of low resource priority, and that managers were more interested in managing within their resource constraints than addressing the policy problem. There are also criticisms that many areas of public policy breed increased dependencies and that the bureaucracy and delivery agencies are often complicit in this rather than lessening dependencies (for example, middle-class welfare, rental or wage supplementation schemes). This is especially pronounced in the social, community and health sectors, the childcare industry, and of certain client types - such as families, farmers, and the disabled.

It is also dubious whether the outcomes framework really applies to central agencies that either have coordination functions or process functions that do 
not easily fit a results-based framework. Arguably, the imposition of a one-sizefits-all 'outcome framework' that may suit sectoral or client-based agencies does not apply as well to central agencies (Australian Public Service Commission, Attorney-General's Department, Prime Minister and Cabinet, Treasury, Finance) and most of the foreign affairs and national security organisations - or any other entities without tangible outputs (and some agencies do report that they have no outputs or only have loose output groups). Their activities are principally internal advice, policy analysis and review, and corporate governance. As one Treasury official said, most of the activity under the outcome statement 'sound macro-economic environment' involved Treasury preventing silly schemes and crackpot ideas from being advanced or accepted, especially from ministers sometimes even their own minister - and from various sectional interests (see Wanna 2011). The outcome 'sound macroeconomic environment' in reality consists of Treasury providing policy advice, analysis and forecasting to the government. It was also hard to demonstrate effectiveness in performance terms, especially if Treasury had prevented bad policy advice going through.

Taking these criticisms together, there is an accepted mythical or fictional dimension to the 'outcomes framework'. Most of the budget is not allocated by outcomes, even though it can be presented as if it were. Most funding and allocative decisions are not based on the priority of the outcome to government, but on the organisational units that have been swept under that particular outcome label for presentational purposes. By some estimates, less than 7 per cent of the budget is formalised according to notions of outcomes - the rest by standing appropriations and departmental items (the old running costs system). After years in operation, many agencies do not appear to have structured their organisations around the outcomes framework, but instead prefer to structure their operations according to activities, business groups or organisational entities. There are questions of how far these generic indicators of government priorities are integrated into the real operations of government agencies (see ANAO 2006). As the Labor Party argued in 'Operation Sunlight' while it was in opposition, many outcomes and the documents relating to them are 'virtually meaningless' and 'open slather for political pork-barrelling' (Tanner 2006).

As Allen Schick (2007) said on a visit to Australia, 'why does Australia persist with a budgetary system that no one believes is working?' In his own inimical way he was highlighting the apparent contrast between the formal rules and the practical reality. Another senior public servant not from a budget agency claimed that one of the present-day major challenges for government was 'how to make the outcomes and outputs framework work - especially when there were claims it would turn the world around, and it hasn't'. The next big budgetary debate in Australia should address the issue of whether to enhance the outcomes-outputs framework or to replace it with an alternative system. 
Elsewhere in the budget processes, some key institutions, such as the ERC, may now have outlived their principal usefulness. This high-level budget review committee can trace its antecedents back to 1975, but has been accused by senior officials across government of distorting policy-making and impeding good decision-making. It can often discourage agencies from making submissions for fear of losing resources under the operations of the offsets requirements - having offsets confiscated as cuts but not gaining acceptance for the new proposal. Agencies have learnt to bypass ERC or to game the system by massaging the types and levels of funds for which they apply (one or two big items or 'majors' or lots of 'minors'). Defence and national security proposals now bypass ERC entirely and go through their own budgetary evaluation process (the national security committee of Cabinet) which is not linked to the ERC process but has its own aggregate limits imposed by Cabinet. ERC was once the lynchpin of collective decision-making premised on assessing all policy comparatively at one point in time in the budget cycle. Other agencies have now resorted to using other political tactics to secure resources outside the formal budgetary process (strong ministers, exceptional cases, infrastructure needs, regional priorities, etc.) where they stand greater chances of success and can circumvent the normal budgetary rules.

With Labor again coming back into government after winning the 24 November 2007 election, they had the opportunity to fundamentally review the budget framework and the internal budgetary processes. 'Operation Sunlight' had promised a range of reforms (to disclosure and reporting, tightening the outcomes framework, etc.) and the new Finance Minister, Lindsay Tanner (2008), committed the government to a phased-in series of reform initiatives (16 in total), and invited the former Australian Democrat Senator Andrew Murray to conduct a forensic review of budgetary accountabilities (Murray 2008). But no sooner had these intentions been announced than the global financial crisis hit Australia and the government's enthusiasm for reform evaporated.

\section{Dead ends, dry gullies and unintended consequences}

As mentioned earlier, budget reformers and central budget agencies often paint a glorious triumphal picture of the reform journey. However, on a day-to-day basis, reform ideas often occurred spontaneously in different parts of the system. System changes could occur unexpectedly or as an unintended by-product of some other change. Assessments of what can be attempted or achieved has often meant that second- or third-best alternatives were explored and trialled. Some changes appear now to have been almost random experiments. Looking back, 
there have been many procedures and budget rules adopted as leaps of faith or with great hopes, but which have been quietly disposed and denied when they are no longer found appropriate. I will mention a few of these below.

Portfolio budgets emerged in the 1980s as a result of aiming to implement program budgeting. Program budgeting was never adopted (although some new measures on the margins may have received direct program allocations). Instead, Australia chose to budget for portfolios, as Pat Barrett (1988) has argued, and within that envelope of funds the various ministers and agencies could have various program structures and move funds between them over time (allowing fungibility). The myth of introducing program budgeting was partly maintained as the Department of Finance consolidated running costs into oneline appropriations — but not on a program by program basis — hence agencies had no program budget per se, but consolidated running costs they could apply across whatever program, business lines or corporate structures they chose. For around a decade Finance pretended it could distinguish between 'program costs' and 'running costs' and keep the two separate, but prior to the accruals framework these two labels tended to overlap or be substitutes for each other. Some agencies creatively gamed the new rules. The ABC, for instance, argued that because it made TV 'programs' all its costs were therefore program costs — and so not subject to the efficiency dividend - it claimed not to have any 'running costs'.

Although Australia did not deliberately plan to install portfolio budgeting, it worked at the political and administrative level. Yet once accrual budgeting was adopted in 1999-2000, the government (perhaps unintentionally) sacrificed portfolio budgets in favour of agency-based budgets, which has reduced flexibility and increased silo thinking. A clear unintended consequence of accruals was the compartmentalisation of agencies as single budget agencies, in essence dealing with the central budget agency directly. The techniques or ideology behind accruals meant that entities had to be directly responsible for the control and management of their resources; hence the way financial resources were identified and recorded by accountants at an agency level shaped the distribution of resources. This process of compartmentalisation was underscored by the 1997 FMA and CAC Acts, which held the head of agency or CEO to account as the accountable officer for financial resources. A further unintended consequence was that, under accruals, agencies were effectively given non-lapsing appropriations which, if not spent within the approved year, could be spent in the future for the purpose identified in the appropriation leaving some to question the constitutional legitimacy of this practice.

In 2000-01, the government committed itself with much fanfare to pricing reviews as a way of improving the efficiency of cost structures in government (see Kelly and Wanna 2004). Despite the problem of identifying prices when so 
much of what the government did had no market price or was not subjected to market disciplines, the government persevered with this innovation. Pilot studies of agencies were undertaken before more widespread pricing reviews were attempted, but the results were disappointing. There were two main findings that appeared: there was much arguing about what constituted 'price' or what methodologies were appropriate to calculate this figure; and it was not clear that much had been achieved in terms of useful information. The only possible exception being that the only price comparisons which could be made with any rigour were for common services and activities such as human resources, finance, and parliamentary services. Pricing reviews were quietly dropped as both guardian and spending departments realised their limitations or futility.

In 1996-97 the Howard government formally embraced the purchaser-provider model for service delivery and outsourced provision based on tight contracts (National Commission of Audit 1996). It viewed this as a way to contain costs, allow devolved forms of delivery (sometimes using different or competing delivery modes), and being able to hold providers to account for results. There was also some discussion of offloading responsibilities, and perhaps even some component of accountability (although the Auditor-General consistently argued that accountabilities could not be 'outsourced'). After the major debacle with the compulsory outsourcing of IT in the late 1990s — when two Cabinet decisions contradicted each other, one to go ahead and the other to delay - the Howard government downplayed its enthusiasm for adopting the purchaser-provider split as a panacea for all government services. Instead, the Commonwealth spoke of funder-provider relations and grant-based assistance schemes where the aim was not to 'purchase' a service entirely using contracts, but contribute to desired outcomes in the community (for example, support of childcare centres, family support programs, etc.). The Commonwealth does not accept sole responsible for the final activity but makes funding contributions or subsidies available to those providing the service. Some of these funder-provider schemes operated through the states (for example, programs for health and housing, the disabled and homeless), and states for their part have largely refrained from participating in these programs as contractual providers. In the community sector, many of these non-government 'providers' are not-for-profit organisations that deliver a range of existing services, not necessarily only those that receive federal contributions. Faced with such difficulties, the Commonwealth generally abandoned the purchaser-provider model except in the area of employment services where the Department of Employment and Workplace Relations has attempted to make the model work through private-for-profit providers and corporate arms of voluntary organisations. 
Vouchers were also mooted as a way to empower clients and citizens and reroute funding through the end-users rather than the organisational deliverers. Health and education were proposed as the major sectors where such 'buyerschoice' schemes could be trialled. A former education minister, David Kemp, tried in vain to shift educational funding to the recipients rather than to institutional providers. But after a decade virtually no voucher schemes have been introduced - although some quasi-schemes involving limited portability have been used (for example, postgraduate scholarships for graduates that go where the student elects rather than being allocated to a particular university, or childcare subsidies or rebates paid to the parent rather than the centre). Again, discussion of voucher-driven funding models has largely abated.

Evaluation has long been the holy grail of the managerialists, many of whom were anxious to show value for money and establish systematic methods of improving policy design and undertaking policy learning. Various schemes have been implemented, none of which has been continued after an initial experimental phase. We have seen a succession of evaluation exercises since the 1970s: joint management reviews, program reviews, appropriateness reviews ordered by Cabinet, compulsory schedules of three- and five-year evaluation reviews, lapsing program reviews, and more recently strategic or cluster reviews. All imposed large investments of resources (especially time), not necessarily to much effect. Many of the evaluation schemes relied on the reviewing agency doing the review or being centrally involved in it, which then undermined the credibility of the findings. Other reviews were used tactically to try to justify more resources for a program in subsequent budget rounds. Each form of evaluation, with the exception of the Auditor-General's efficiency or performance audits (which do not quite fulfil the same function), was terminated, usually within a short period of being announced. Lapsing reviews, for instance, were discontinued when the volume of work for agencies after about three years was so great they could not justify the effort involved. Program lapsing reviews were replaced by cluster reviews of related services as programs came up for renewal. It will be interesting to see whether they fare better than their predecessors. The sorry history of repeated attempts to introduce workable and effective evaluation processes has moved many senior officials to question why policy evaluation has never got off the ground in Australia.

Other dead ends and dry gullies have included:

- the experiment with agency banking undertaken in 1999, but reversed later so that the Department of Finance could practice better cash management;

- the capital use charge initially set at 11-12 per cent (on a base of 6 per cent plus risk margin), with agencies funded for capital at the outset of the budget year but then charged for their capital usage at the end of the year (allowing 
them to keep any 'savings'), recommended by accountants - the measure did not prove any assistance in the management of assets and tended to remain an accounting exercise;

- the experiment with devolving the construction of expenditure estimates to line agencies has been gradually reined in by Finance following a succession of missed accuracy targets (revenue estimates have been even more off target) - agencies still input the raw data but Finance now has the final say on what the estimates will be;

- devolved procurement was meant to enable agencies to arrange and control the costs of their own procurement, but the policy was recentralised under new guidelines issued in 2005 .

\section{The travails of budgetary reporting: Distorting the glass darkly}

Budget documentation is ostensibly produced for accountability and scrutiny purposes, but arguably has now been overshadowed by marketing and presentational considerations. Governments are judged on their budgets by many diverse audiences, so the baroqueness of budget presentation is now assured. Governments have long used budgets to gild the lily, disguise realities, and convey favourable impressions.

Despite the Charter of Budget Honesty (which required more integrated reporting but which still has many problems: see Wanna 2006), budget documentation is now more confusing, and in certain respects less informative and nontransparent. Allan Barton (2006) once calculated that up to nine different measures of budget balance or outcome can be found in budget documentation, and treasurers tend to hop backwards and forwards to their preferred sets of figures. So, from year to year we have seen various treasurers talking about the fiscal balance, the underlying cash balance, the headline balance and the size of the surplus to GDP. The most wanton disregard for accuracy and disclosure came with the Coalition government's deliberate non-counting of the GST revenues in the Commonwealth accounts (instigated by Treasurer Peter Costello), despite the Australian Bureau of Statistics (ABS) and Auditor-General both arguing these revenues should be included. By not including the GST all manner of falsehoods were perpetrated, especially when calculating comparative spending patterns, such as the magnitude of Commonwealth revenues to GDP, the size of the Commonwealth government in OECD material, comparative expenditures across governments, and internal proportions of spending which are distorted because a large chunk of transfers to the states are not included. This tax was not counted largely because the former Treasurer had earlier promised to cut 
Commonwealth outlays from the levels reached under Keating (from 27 per cent to 23 per cent); discounting one-sixth of the budget was his way of giving the illusion the Commonwealth had shrunk since 1996 (see Wanna et al. 2000, p. 258). It also avoided any impression that the Commonwealth tax per capita had increased during the life of the Coalition's tenure in government. The exclusion of the GST was made solely at the insistence of the former Treasurer while the incoming Rudd government announced its intention to reverse this stance and recalculate expenses from 2000, which it promptly did. Such sophistry over the GST did not prevent the previous government occasionally threatening to put 'conditions on GST transfers' if states do not comply with some federal wish or dictate. So, in spite of the sentiments expressed in the Charter of Budget Honesty, the government could well be open to charges of giving deliberate misinformation or partial reporting.

In relation specifically to the reports required by the charter, the legislation was introduced with good intentions but was corrupted by political circumstance and occasionally sidelined. The government made political mileage about its commitment to look at long-term demographic impacts to the budget. Yet in 2001-02 as the intergenerational report was due, the government became bogged down in the detail and had to pull material together at short notice (the statement seemed to have been overlooked). Treasury produced the first report without involving other research units across government such as the ABS. The second report was produced in-house, led by a Treasury team. Circumstances have also seen various financial reports politicised, such as when Peter Costello released a separate Mid-Year Economic and Fiscal Outlook (MYEFO) report, which he claimed was 'more accurate' the day before his department released the real one, and then refused to discuss the departmental report. The process of costing election commitments is at present hopelessly compromised meaning the provisions of the Act - which could be beneficial to parties in the lead up to the election - are largely made ineffective (for example, evaded, delayed or used simply in costing 'saving' measures). The release of the 2007 MYEFO in October 2007 was slightly early, suiting the government's election timing - and half the report was a detailed exposition of the Howard government's intended tax cuts for the period up to 2010 - and subverting the intent of the report, which was to be a mid-year progress report on actual movements since the last budget. Such examples indicate governments are motivated to use these reports expediently as a convenient vehicle for their own political purposes.

The preference for reporting against a selected results-based format has come at the cost of detailed input information and detailed activity information. Whereas many large private corporations collect detailed information on the bases of both results and input costs, and report on key changes continuously, governments have now scaled back their presentation of input data, relying 
on annual accrual financial statements to tell the financial story. Despite parliamentary committees recommending greater program information to go with other budgetary documentation (for example, in portfolio budget statements) the government has steadfastly refused to provide this information, claiming it would only add levels of confusion to the available documentation. Finance already collects much of this input and program information, but the Howard government chose not to release it. Labor committed itself to producing greater input transparency and program performance data on coming to office, but it remains to be seen whether it would honour such commitments.

The usefulness of budget information to readers, inside and outside of Parliament, is also open to debate. Understanding of accrual financial information requires a basic technical accounting knowledge, which does not come naturally to politicians and lay commentators. For example, the implications of asset sales on net worth and future earning capacity get barely any attention compared with the consequences of increased receipts for surplus cash available to be used.

There is still a huge asymmetry in the annual budget presentation. Governments almost exclusively give prominence to new initiatives and priorities announced through their budgetary parameters, providing little new information on ongoing measures and commitments other than forward estimates. Some agencies in their annual reports do provide informative details and highlight innovations in their base budget activities - but often 12-15 months after the event. The attention given to special appropriations, which lock-in over 80 per cent of total Commonwealth expenditure each budget, is almost insignificant compared with the detailed information on departmental outputs, which comprise around 15 per cent of annual expenses.

There are some other small, simple issues that have reduced transparency for no apparent reason. The government now chooses not to produce historical graphs of functional outlays/expenses - as it did prior to 1999 - which showed comparative spending data in a sectoral area over time. Such 10-15 year graphs allowed readers to observe what patterns were unfolding, where blow-outs were occurring, where tightening or deprioritisation had been made, and which functions were declining in importance. For a while, no functional data was presented at all, but after some parliamentary feedback an annual table has been included in the budget, but only with that year's functional expenses shown (but at a high level of functionality).

For a couple of years in the 1980s, the government also courageously produced 'offset savings' graphs, showing the offsets 'captured', the recycling of money, and how much offsets contributed to new policy proposals. They then terminated this experiment. In 1996 the Howard government produced a report 'Meeting Our Commitments', which listed the magnitude of the various savings measures 
across government, and where the savings were made, but the government never repeated this exercise. Readers have to search through individual agency portfolio additional estimates statements for records of savings. But even this information is often unsatisfying, as it frequently records book transfers associated with reductions in estimates rather than true savings.

Performance claims by agencies are not usually audited or subject to independent scrutiny (although some could be taken up in performance audits). Many outcomes cannot be closely tied to performance indictors or even to definable outputs. Yet governments do not externally report performance against programs that would give Parliament a good indication of actual performance in agencies. In terms of reporting, the outcomes framework assumes the Commonwealth does things and delivers directly, when in fact it often does not. Agencies process benefits and other transfers according to conditions set by Parliament, provide grants and co-fund activities performed by others, or make contributions to services (health, housing, childcare, environmental management, family income maintenance, etc.). The effectiveness and efficiency of government spending in these activities is virtually impossible to measure in a meaningful way and cannot easily be attributed to the Commonwealth. Line agencies are often aware of this problem, but the issue has not fully crystalised at the centre of government.

In budgetary reporting we have frequently changed the formal requirements and added the emphasis on reporting impact intentions (perhaps for the better), but we have a long way to go to find an appropriate balance of disclosure and provide meaningful information.

\section{Some key propositions and observations from Australia's trajectory of reform}

Looking back on the trajectory of reform over the past 30-40 years, the following propositions are apparent.

First, governments seem quickly to run out of steam in undertaking budgetary reform. Three to five years seems to be the norm for reform - in the government's first and perhaps second terms especially. They can criticise their predecessors and inherited systems, they have their own new agendas and priorities, and they have enthusiasm as a new government to make changes. They then tire of the reform commitment, are satisfied with their handiwork, and will not allow or contemplate further changes. Two good examples will suffice: the Hawke government (1983-91) introduced most of its budget reform between 1984 and 1987, after which it held the system in place with some gradual adaptations; 
the Howard government (1996-2007) introduced its accrual-based outcomes/ outputs framework in 1999 and then largely left the framework unchanged since implementing it. This suggests budget reform itself has a life cycle: conception, development, implementation and consolidation followed by stagnation.

Second, contrary to the allure of 'strategic budgeting', budgets tend to drive policy (not vice-versa), or, put alternatively, form and process drives strategy. The enshrinement of agency-level base budgeting within the outcomes framework further limits the potentiality of budgets to be strategic. If we want to achieve greater strategic direction, we may need to change the way we budget first. There are other models from which we can draw; we may need to strengthen and redesign the 'challenge function', where existing programs are systematically challenged in regard to their continued relevance and effectiveness; we may need to reconsider ways to achieve greater levels of reallocation (including with transfers and entitlements); or we may need to readdress the incentive structures and dependencies between governments and citizens.

Third, at the same time as we have reformed budgeting - especially on the expenditure side, focusing more and more on the smaller discretionary component - so the budget itself has become less important to the economy (and, arguably, to governments and the policy process). Much of the budget works on auto-pilot (consumer price adjustments to programs, bracket-creep with income tax, depreciation schedules, pension and benefit adjustments, etc.). We have structured budget processes to remove the scope for discretion. Surplus funds have been moved into special accounts and quarantined funds (such as the Future Fund, Education Fund and Infrastructure Fund) where discretion is limited. The budget is heavily geared towards transfer payments and citizen entitlements governed by standing appropriations. Governments themselves often recognise this - that is why so much of political presentation on budget day is take up with tax cuts, distractions, proposed future funds or foundations.

Fourth, while much of the Australian budget reform trajectory aimed to consolidate a formerly fragmented set of processes, the system has begun to re-fragment. We set out to prevent cabinets making decisions without costings, without Treasury analysis, and without being able to make assessments of comparative worth of projects and programs. Hence, we consolidated budgetary processes, designed specially tailored Cabinet processes, and argued for annual consolidation and prevention of out-of-budget spending wherever possible. We sought control and we largely achieved it. Then budgets began to be more about 'facilitation' and we relaxed the tightness in process - much of it deliberately. This occasionally comes back to haunt us (for example, the 2007 water announcement of $\$ 10$ billion, which was not costed or authorised by Cabinet). We have gone through a roller coaster from fragmentation, to control and consolidation, to re-fragmentation. Relaxed controls appear to have suited 
the political style of the day especially in a post-9/11 security context. But the fragmentation of decision-making comes at a price to the detriment of good governance and strategic leadership.

Fifth, relationships between budgets and performance are difficult and problematic. It is hard to combine or integrate these without avoiding unwanted consequences, perverse or distorting incentives, gaming or capture. While governments constantly talk of relating and integrating performance to budget allocations, they have found it difficult to do in practice. Maybe we should keep these two functions separate and discrete while concentrating on finding better ways to have dialogue between them. We have a long way to go here.

Sixth, we need to appreciate that budget processes not only provide possibilities and scope for governments to do things, but also impose restraints on what governments can do and how they do it. There will always be a tension between these competing forces - the desire for efficiency and effectiveness versus integrity and accountability. These are not the same things, and there is little evidence that they are conflating under new public management or outsourced forms of delivery.

Seventh and finally, although governments talk about the benefits of wholeof-government approaches and meeting priorities together, ministers are still risk averse about interdepartmental collaboration. Budgets allocate to silos, and accrual budgeting has unintentionally made the situation worse, not better. We need to find ways to resource whole-of-government initiatives that give these items the high priority that governments claim.

\section{Appendix 1: What would a 'strategic budget' look like, and who can play the strategic role?}

If budgets serve as routine planning instruments, to what extent are they capable of being strategic or of enhancing strategic decision-making? This question raises the age-old public finance issue of effective collective choice between competing alternatives - guns or butter, war or peace, productivity versus lifestyle choices. It also raises the issue of how far resources can be reallocated, and whether inherited allocations remain strategic or need to be changed.

In more recent times, this conundrum has been depicted as the search for the holy grail of 'strategic budgeting' — theoretically conceived notions of strategic decisions leading budgetary allocations, and policy leading financial decisions.

What, then, might a strategic budget look like? How are the terms 'budgeting' and 'strategic decision-making' linked, or how can they be linked? What would 
be the perceived benefits of a strategic budget process? The term 'strategy' is much over-used, and has many different meanings and interpretations. For politicians, 'strategy' often translates into 'popular', 'successful', 'winning options'. Ministers may only have broad and amorphous notions of strategic directions (ideas, priorities, immediate goals) that need to be integrated with operational concerns. For administrators, words such as 'consistency', 'direction' and 'integration' often come to the fore. In most cases, bureaucrats become concerned with strategic direction, meaning that 'strategy' is often a bureaucratic discourse - part of preparing themselves to be responsive to political/government priorities.

Officials generally consider a strategic budget — or a strategic-driven budget process - as a blueprint or coherent overall plan, making sense of resource determinations and providing unambiguous direction. To many, it would ideally include the following characteristics:

- clear directions and articulation of objectives and priorities;

- policy decisions drive the finances and allocative efficiencies;

- the focus is on the budget in total not on the margins;

- governments look to longer-term time frames and anticipatory planning in relation to future expected demands;

- more reliable information on results and outcomes achieved;

- indications of relative success are acknowledged and maintained; and

- the processes of budget-setting align with the government's strategy.

This is not the system of budgeting we see today in Australia, although elements can be detected in the present practices.

\section{References}

ALP (Australian Labor Party) 1983, 'Labor and Quality of Government'.

ANAO (Australian National Audit Office) 2006, 'Application of the Outcomes and Outputs Framework', Audit Report No. 23, 2006-07.

Australian Government 1984, 'Budgetary Reform', AGPS, Canberra.

Barrett, P. 1988, 'Emerging Management and Budgetary Issues: The view from the centre', Canberra Bulletin of Public Administration 54. 
Barton, A. 2006, 'Sense and Nonsense in Government Accrual Accounting and Budgetary Systems', in B. S. Grewal and M. Kumnick (eds), Engaging the New World: Responses to the knowledge economy, Melbourne University Press, Melbourne.

Castles, F. 1999, Comparative Public Policy: Patterns of post-war transformation, Edward Elgar, Cheltenham.

Chan, M., M. Nizette, L. La Rance, C. Broughton and D. Russell 2002. 'Australia', OECD Journal on Budgeting.

Department of Finance and Administration 1998, 'Specifying Outcomes and Outputs: Implementing the Commonwealth's accrual-based outcomes and outputs framework'.

Di Francesco, M. 1998, 'The Measure of Policy?: Evaluating the evaluation strategy as an instrument for budgetary control', Australian Journal of Public Administration 57(1), pp. 33-48.

Graycar, A. 2007, 'Central Agencies: Leadership or treading on toes', Public Administration Today 12.

Graycar, A. and B. McCann 2012, 'Implementation: Making hard work of something simple', Australian Journal of Public Administration 71(3).

Halligan, J. 2004, 'The Australian Public Service: Redefining boundaries', in J. Halligan (ed.), Civil Service Systems in Anglo-American Countries, Edward Elgar, Cheltenham.

Heclo, H. and A. Wildavsky 1974, The Private Government of Public Money, Macmillan, London.

Henry, K. 2007, 'Treasury's Effectiveness in the Current Environment', speech to Treasury staff, 14th March.

IMF 1999, 'Code of Good Practices on Fiscal Transparency'.

Keating, M. 1989, 'Quo Vadis?: Challenges of public administration', Australian Journal of Public Administration 48(2).

Keating, M. 1990, 'The Processes of Commonwealth Budgetary Control', in J. Forster and J. Wanna (eds), Budgetary Management and Control, Macmillan, Melbourne.

Keating, M. and G. Dixon 1989, Making Economic Policy in Australia, 19831988, Longman Cheshire, Melbourne. 
Keating, M. and M. Holmes 1990, ‘Australia's Budgetary and Financial Management Reforms', Governance 3(2).

Kelly, J. and J. Wanna 2001, 'Are Wildavsky's Guardians and Spenders Still Relevant?: New public management and the politics of government budgeting', in L. Jones, J. Guthrie and P. Steane (eds), Learning From International Public Management Reform, Elsevier Science, Amsterdam.

Kelly, J. and J. Wanna 2004, 'Crashing Through with Accrual-Output Price Budgeting in Australia', American Review of Public Administration 34(1).

Laurie, K. and J. McDonald 2008, 'A Perspective on Trends in Australian Government Spending', Commonwealth Treasury, Canberra.

Management Advisory Board 1997, 'Beyond Bean-Counting: Effective financial management in the APS - 1998 and beyond', Management Advisory Board, Canberra.

Minchin, N. 2006, Speech to the 27th Annual Meeting of Senior Budget Officials of the OECD, Sydney, 5th June.

Murray, A. 2008, 'A Review of Operation Sunlight: Overhauling budgetary transparency', Report to the Finance Minister, Andrew Murray, June.

National Commission of Audit 1996, 'Report of the Commission', AGPS, Canberra.

New Zealand Treasury 1984, 'Economic Management', Wellington.

OECD 2001, 'OECD Best Practices for Budget Transparency', May, Paris.

OECD 2004, 'Senior Budget Officials Newsletter', February.

O'Faircheallaigh, C., J. Wanna and P. Weller 1999, Public Sector Management in Australia: New challenges, new directions, Macmillan, Melbourne.

Parliament of Australia 1995, 'Financial Reporting for the Commonwealth: Towards greater transparency and accountability', Joint Committee of Public Accounts, November.

Parliament of Australia 1998, 'Charter of Budget Honesty Bill 1996', Bills Digest No. 142 1997-98.

Schick, A. 2001, 'The Changing Role of the Central Budget Office', OECD Journal on Budgeting 1(1).

Schick, A. 2002, 'Does Budgeting Have a Future?', OECD Journal on Budgeting $2(2)$. 
Schick, A. 2007, Presentation to ANZSOG Seminar: Public Budgeting, ANU, Canberra.

Senate Standing Committee on Finance and Public Administration 2007, 'Transparency and Accountability of Commonwealth Public Funding and Expenditure', Commonwealth of Australia, March.

Tanner, L. 2006, 'Operation Sunlight: Enhancing budget transparency', ALP, Canberra.

Tanner, L. 2008, 'A List of Labor's Proposed Reforms', email to David Uren, The Australian from Finance Minister, 14 April.

Walsh, P. 1995, Confessions of a Failed Finance Minister, Random House, Sydney.

Wanna, J. 2006, 'Between a Rock and a Hard Place: The nonsense of Australia's Charter of Budget Honesty Act 1998', paper delivered to the Australasian Political Studies Association conference, Newcastle.

Wanna, J. 2011, 'Treasury and Economic Policy: Beyond the dismal science', Australian Journal of Public Administration 70(4), pp. 347-364.

Wanna, J., L. Jensen and J. de Vries (eds) 2003, Controlling Public Expenditure, Edward Elgar, Cheltenham.

Wanna, J., L. Jensen and J. de Vries (eds) 2010, The Reality of Budgetary Reform in the OECD Nations, Edward Elgar, Cheltenham.

Wanna, J., J. Kelly and J. Forster 2000, Managing Public Expenditure in Australia, Allen \& Unwin, Sydney.

Wildavsky, A. 1964, The New Politics of the Budgetary Process, Pearson Longman, New York.

Wildavsky, A. and N. Caiden 2004, The New Politics of the Budgetary Process, 5 th ed., Pearson Longman, New York. 
This text taken from New Accountabilities, New Challenges, edited by John Wanna, Evert A. Lindquist and Penelope Marshall, published 2015 by ANU Press, The Australian National University, Canberra, Australia. 